\title{
FEATURES OF INSULIN RESISTANCE ASSESSMENT IN PATIENTS WITH TYPE 2 DIABETES MELLITUS WITH HYPERURICEMIA*
}

\author{
Cherniaieva A. A. \\ State Institution «V. Danylevsky Institute for Endocrine Pathology Problems \\ National Academy of Medical Sciences of Ukraine», Kharkiv, Ukraine; \\ Kharkiv Medical Academy of Postgraduate Education, Ministry of Health of Ukraine, Kharkiv, Ukraine \\ annakholodnaja2008@gmail.com
}

Research conducted over the past century has found that purine metabolism disorders lead to a cascade of pathogenetic reactions, their consequence being a disorder of other types of metabolism. There is currently a considerable interest in the impact of uric acid, a product of purine metabolism, on the development of type 2 diabetes (T2DM) and its complications [1, 2]. Notably, several epidemiological studies have demonstrated graded associations between baseline serum uric acid (SUA) and subsequent T2DM [3-5]. Meta-analyses have reported a $6 \%$ to $17 \%$ higher risk of T2DM for every $1 \mathrm{mg} / \mathrm{dL}$ increment in SUA [6, 7].

SUA levels are related to insulin resistance (IR) and body mass index (BMI), rather than insulin levels, suggesting that obesity-driven metabolic syndrome as a major determinant of its levels [8]. Experimental studies show that hyperuricemia (HUA) promotes the occurrence and development of cardiovascular diseases by regulating molecular signals, such as inflammatory response [9], oxidative stress [10], endothelial dysfunction [11] and endoplasmic reticulum stress [12].

The author used direct, indirect, and computational methods to estimate IR [13, 14]. Direct methods for assessing IR include: insulin tolerance test, insulin suppressive test, and euglycemic hyperinsulinemic "klamp» a test that determines the effect of an insulin infusion on glucose metabolism. The latter is considered the most informative, sensitive, and specific method [15-17]. Indirect methods (oral and intravenous glucose tolerance tests and continuous glucose infusion with model assessment) evaluate the effect of endogenous insulin. In routine clinical practice, we main-

* The research was done at the Department of Clinical Endocrinology of the State Institution «V. Danylevsky Institute for endocrine pathology problems National Academy of Medical sciences of Ukraine» within the framework of the topic «Research of purine metabolism disorders impact on the development and progression of diabetes mellitus» (state registration number 0116U007261).

Institution, which financed the research: Ministry of Health of Ukraine.

The authors assume responsibility for the published work.

The authors guarantee absence of competing interests and their own financial interest when carrying out the research and writing the article.

The manuscript was received by the editorial staff 1.08.2021. 
ly use computational methods for evaluating IR-mathematical models that reflect the sensitivity of tissues to insulin $[14,18]$.

The most popular among well-known models are «insulin» indices HOMA (HOmeostatic Model Assessment - method for evaluating the homeostatic model) [19], Caro, QUICKI (QUantitative Insulin ChecK Index - index for quantifying insulin sensitivity) [20, 21]. Despite relative availability of «insulin» indexes, the search for cheaper, easier, and easier-to-use methods for assessing IR continues. A number of "non-insulin» IR indices have been proposed, calculated using anthropometric and laboratory tests that are widely used in clinical practice. Examples of such «non-insulin» indices are the visceral obesity index (AVI) [22], ТуG-індекс (Triglycerides and Glucose index - triglyceride-glucose index) [23], metabolic index (MI) [24] and the triglyceride ratio (TG)/high-density lipoprotein cholesterol (HDL-C) (TG/HDL-C-ratio) [23].

Quite a few studies have demonstrated association between HUA and IR but the traditional IR indexes are too impractical to be used in clinical practice recognizing the IR state in individuals with HUA.

The aim of the research is to evaluate the possibility of using non-insulin-based IR indexes in clinical practice to assess IR in patients with T2DM and HUA.

\section{MATERIALS AND METHODS}

The study was conducted in accordance with the legislation of Ukraine and the principles of the Helsinki Declaration of human rights. The design of the study, information for the patients and the form of informed consent to participate in the study were reviewed and adopted by the Ethics Commission of the State Institution «V. Danylevsky Institute for Endocrine Pathology Problems National Academy of Medical Sciences of Ukraine». 395 patients were examined for T2DM (231 women and 164 men) aged 39 to 81 years, average - $(54,6 \pm 12,9)$ years. The author evaluated the duration of the disease and the patients' age at the time of the disease manifestation. The subjects received oral hypoglycemic therapy.

Anthropometric studies included: measuring height $(\mathrm{m})$ - patients were examined using a Harpenden medical mechanical height meter; body weight $(\mathrm{kg})$ - on electronic scales Beurer GS 20 Summer Sky with measurement accuracy up to $100 \mathrm{~g}$ (maximum weight $180 \mathrm{~kg}$ ); waist circumference (WC) $(\mathrm{cm})$ - the patient was measured in an upright position in the middle of the distance between the lower edge of the chest and the crest of the dead bone along the mid-axillary line; BMI $\left(\mathrm{kg} / \mathrm{m}^{2}\right)$ calculated as the ratio of body weight $(\mathrm{kg})$ to height $\left(\mathrm{m}^{2}\right)$.

The analysis of clinical and biochemical parameters included determining the level of fasting plasma glucose (FPG, mmol/L) two hours after the meal (PPG, mmol/L) glucose oxidase method using an express analyzer «Biosen C line»; glycosylated hemoglobin level $\left(\mathrm{HbA}_{1 \mathrm{c}}, \%\right)$, HDL-C (mmol/L), TG (mmol/L), concentration of uric acid in the blood serum (SUA, $\mu \mathrm{mol} / \mathrm{L}$ ), using the colorimetric method. HUA diagnosis was made with $\mathrm{SUA} \geq 420 \mu \mathrm{mol} / \mathrm{L}$ for men and SUA $\geq 360 \mu \mathrm{mol} / \mathrm{L}$ and calculated TG/HDL-C-ratio (c.u).

The author determined immunoreactive insulin levels (IRI, $\mu \mathrm{U} / \mathrm{ml}$ ) by the immunochemiluminescent method, using a kit «Insulin ELISA» (USA).

The degree of IR severity was assessed by the index HOMA-IR c.u), calculated using a certified HOMA Calculator v2.2 for free use [25]. We calculated indexes QUICKI [26] and Caro.

VAI was calculated using the following formulas, as proposed by Amato et al. [27].

$$
\begin{aligned}
\text { AVI }(\text { men }) & =\left(\frac{\text { WC }}{39,68+(1,88 \times \mathrm{BMI})}\right) \times\left(\frac{\mathrm{TG}}{1}, 03\right) \times\left(1, \frac{31}{\mathrm{HDL}-\mathrm{C}}\right) \\
\mathrm{AVI}(\text { women }) & =\left(\frac{\mathrm{WC}}{36,58+(1,89 \times \mathrm{BMI})}\right) \times\left(\frac{\mathrm{TG}}{\mathrm{0}}, 81\right) \times\left(1, \frac{52}{\mathrm{HDL}-\mathrm{C}}\right)
\end{aligned}
$$

TyG-index was calculated using the formula proposed by F. Guerrero-Romero, L. E. Simental-Mendía, M. González-Ortiz et al. [23]:

$$
\begin{gathered}
\text { TyG-index }=\operatorname{Ln}[(\mathrm{TG}(\mathrm{mg} / \mathrm{dL}) \times \\
\times \text { FPG }(\mathrm{mg} / \mathrm{dL}) / 2]
\end{gathered}
$$

TyG-BMI-index (c.u) was calculated as a product TyG-index and BMI [28], TyG-WCindex (c.u) - as a product TyG-index and WC. 
MI was calculated based on the FPG level assessment and indicators of the blood lipid spectrum according to the formula [24]:

$$
\begin{gathered}
\mathrm{MI}=[\mathrm{TG}(\mathrm{mmol} / \mathrm{L}) \times \mathrm{FPG}(\mathrm{mmol} / \mathrm{L})] / \\
/ \mathrm{HDL}-\mathrm{C}(\mathrm{mmol} / \mathrm{L})
\end{gathered}
$$

IR diagnosed by $\mathrm{MI} \geq 7$ c.u.

The author statistically analyzed the obtained data using the software package «Statgraphics Plus for Windows 7.0» (Manugistic Inc. USA). The normality of the variables distribution was determined by the ShapiroWheelk test. Regression analysis was used to identify the relationship between the studied indicators and the normal distribution of variables. The relationship between quantitative variables and abnormal distribution was established using Spearman correlation analysis $\left(\mathrm{r}_{\mathrm{s}}\right)$. Null hypotheses were tested at the significance level $\mathrm{P} \leq 0,05$. The obtained results are given in the tables as $\overline{\mathrm{X}} \pm \mathrm{s}$, where $\overline{\mathrm{X}}$ is arithmetic mean, $\mathrm{s}$ - standard deviation.

\section{RESULTS AND THEIR DISCUSSION}

Clinical and laboratory characteristics of the examined patients on the T2DM in groups based on concentration SUA are given in Table 1.

Abbreviations: NUA, nornaluricemia; HUA, hyperuricemia; BMI, body mass index; WC, waist circumference; VAI, visceral adiposity index; HDL-C, high-density lipoprotein cholesterol; FPG, fasting plasma glucose; PPG, postprandial plasma glucose; $\mathrm{HbAc}_{1}$ glycemic hemoglobin, TG, triglycerides; SUA, serum uric acid; HOMA-IR, homoeostatic model assessment of insulin resistance; TyG, Triglycerides and Glucose index; MI, metabolic index.

\section{Clinical and laboratory characteristics of the examined subjects,

\begin{tabular}{|c|c|c|c|}
\hline Index & $\begin{array}{l}\text { Patients on the } \\
\text { T2DM end NUA } \\
(n=256)\end{array}$ & $\begin{array}{l}\text { Patients on the } \\
\text { T2DM end HUA } \\
(n=139)\end{array}$ & $\mathbf{P}$ \\
\hline Age, years & $52,8 \pm 12,6$ & $57,3 \pm 13,2$ & 0,005 \\
\hline Duration, years & $13,72 \pm 9,35$ & $13,27 \pm 11,07$ & 0,75 \\
\hline Age $_{\text {manifest }}$, years & $39,78 \pm 14,92$ & $44,11 \pm 15,46$ & 0,045 \\
\hline $\mathrm{BMI}, \mathrm{kg} / \mathrm{M}^{2}$ & $29,78 \pm 6,06$ & $32,86 \pm 6,71$ & 0,0002 \\
\hline $\mathrm{WC}, \mathrm{cm}$ & $98,99 \pm 19,15$ & $104,5 \pm 17,56$ & 0,038 \\
\hline $\mathrm{FPG}, \mathrm{mmol} / \mathrm{L}$ & $8,99 \pm 3,00$ & $8,76 \pm 2,89$ & 0,55 \\
\hline $\mathrm{PPG}, \mathrm{mmol} / \mathrm{L}$ & $9,24 \pm 3,02$ & $9,38 \pm 3,23$ & 0,76 \\
\hline $\mathrm{HbA}_{\mathrm{c} 1}, \%$ & $7,48 \pm 1,62$ & $7,52 \pm 1,91$ & 0,87 \\
\hline IRI, $\mu \mathrm{U} / \mathrm{ml}$ & $17,86 \pm 12,83$ & $17,52 \pm 12,48$ & 0,88 \\
\hline SUA, $\mu \mathrm{mol} / \mathrm{L}$ & $279,12 \pm 68,22$ & $476,90 \pm 82,28$ & 0,0001 \\
\hline $\mathrm{TG}, \mathrm{mmol} / \mathrm{L}$ & $1,90 \pm 1,35$ & $2,52 \pm 2,16$ & 0,007 \\
\hline HDL-C, mmol/L & $1,17 \pm 0,29$ & $1,15 \pm 0,30$ & 0,59 \\
\hline HOMA-IR, c.u & $6,38 \pm 4,26$ & $6,89 \pm 5,01$ & 0,55 \\
\hline Index Caro, c.u & $0,57 \pm 0,35$ & $0,69 \pm 0,82$ & 0,46 \\
\hline QUICKI, c.u & $0,21 \pm 0,04$ & $0,21 \pm 0,03$ & 0,59 \\
\hline AVI, c.u & $3,66 \pm 2,41$ & $4,95 \pm 5,65$ & 0,026 \\
\hline TG/HDL-C-ratio, c.u & $1,97 \pm 2,19$ & $2,24 \pm 2,80$ & 0,45 \\
\hline TyG index, c.u & $9,22 \pm 0,66$ & $9,43 \pm 0,80$ & 0,04 \\
\hline TyG-BMI, c.u & $277,53 \pm 63,14$ & $308,61 \pm 71,94$ & 0,0011 \\
\hline TyG-WC, c.u & $918,55 \pm 205,89$ & $980,43 \pm 192,64$ & 0,037 \\
\hline MI, c.u & $16,22 \pm 11,22$ & $23,00 \pm 14,92$ & 0,03 \\
\hline
\end{tabular} taking into account SUA concentration}


We found significant differences between the study groups by WC, BMI and the level TG, as expected. They affected the calculated "non-insulin» indices IR, namely AVI, TyG-index, TyG-BMI-index, TyG-WC-index and MI (see Table.1). Although no significant differences were obtained between the groups by index HOMA-IR, which is the most commonly used in real clinical practice, its value significantly exceeded the normal value (> 2.6 c.u), used for IR diagnostics.

According to the correlation analysis of «insulin» indices, a negative correlation between the indices was established HOMA-IR and Caro $\left(\mathrm{r}_{\mathrm{s}}=-0.74, \mathrm{P}<0.001\right)$, HOMA-IR and QUICKI $\left(\mathrm{r}_{\mathrm{s}}=-0.91, \mathrm{P}<0.001\right)$, positive

$$
\text { TyG } \quad Y=a^{*} X^{*} b
$$

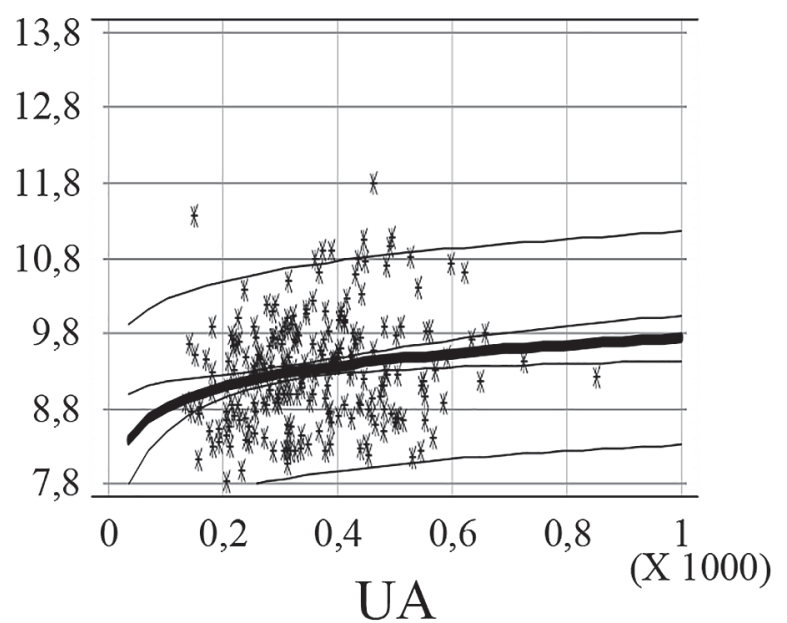

\section{TyG-OT}

$$
Y=1 /(a+b / X)
$$

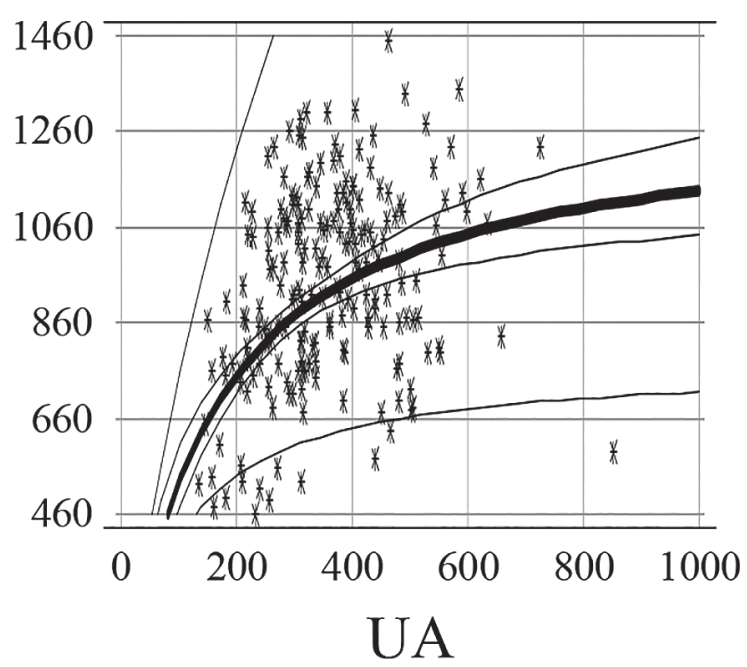

correlation between indices Caro and QUICKI $\left(r_{\mathrm{s}}=0.75, \mathrm{P}<0.001\right)$.

Correlation analysis of the calculated «insulin" and "non-insulin» indices revealed the presence of a positive correlation between HOMA-IR and MI $\left(r_{s}=0.44, \mathrm{P}=0.0006\right)$ that HOMA-IR and AVI $\left(\mathrm{r}_{\mathrm{s}}=0.28, \mathrm{P}=0.01\right)$. The author has established that the Caro index at the trend level positively correlates with TyGindex $\left(r_{s}=0.23, P=0.065\right)$. Index QUICKI positively correlates with $\mathrm{MI}\left(\mathrm{r}_{\mathrm{s}}=0.32, \mathrm{P}=0.012\right)$, TyG-index $\left(\mathrm{r}_{\mathrm{s}}=0.29, \mathrm{P}=0.02\right)$, TyG-BMI-index $\left(\mathrm{r}_{\mathrm{s}}=0.25, \mathrm{P}=0.04\right)$, TyG-WC-index $\left(\mathrm{r}_{\mathrm{s}}=0.34\right.$, $\mathrm{P}=0,004)$ and AVI $\left(\mathrm{r}_{\mathrm{s}}=0.31, \mathrm{P}=0.01\right)$. Thus, five of the six calculated «non-insulin» indices correlated with «insulin» indices HOMA-IR

\section{TyG-IMT}

$Y=1 /(a+b / X)$

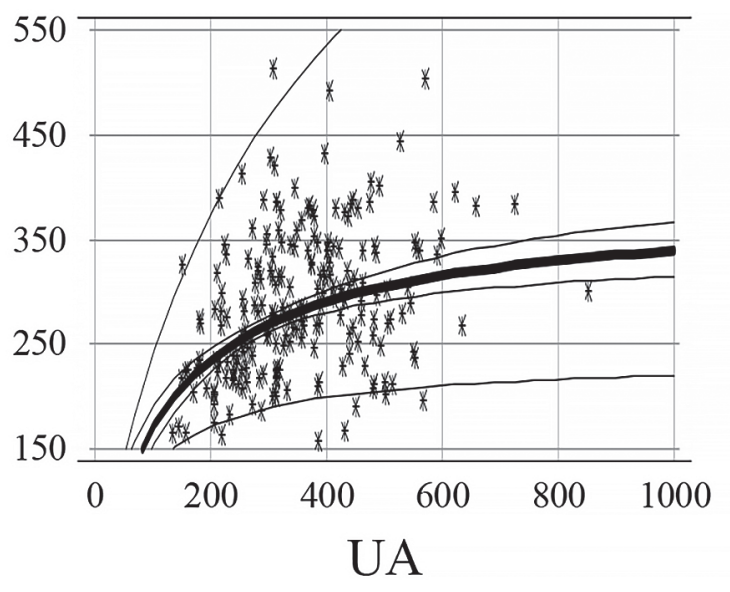

MI

$Y=a^{*} X^{*} b$

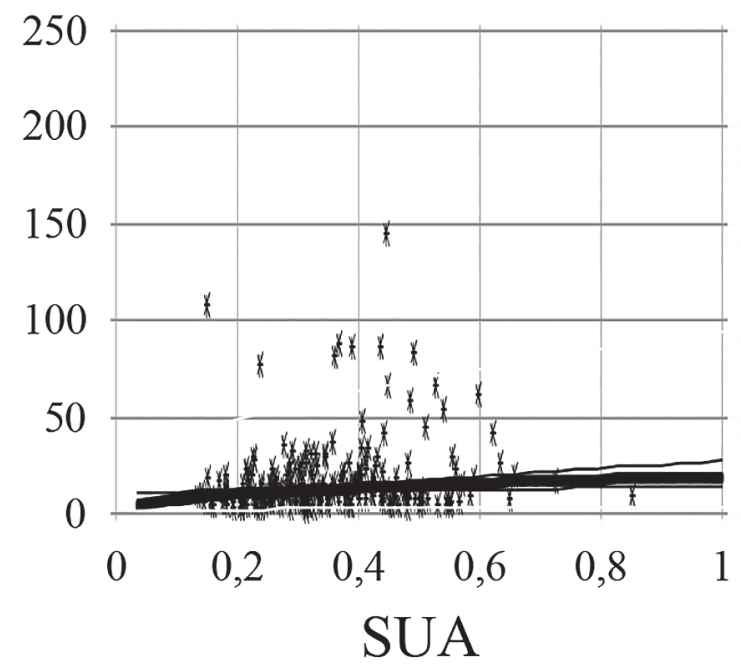

Fig. 1. Value dependency of TyG-index (Fig. 1a), TyG-BMI-index (Fig. 1b), TyG-WC-index (Fig. 1c) and MI (Fig. 1d) on SUA concentration in patients with T2DM. 
and QUICKI. At the same time, none of the studied «non-insulin» indices significantly correlated with the Caro index.

Among all the studied calculated «non-insulin» indices IR with concentration SUA in patients with T2DM, significant associations are found with TyG-index $(\mathrm{r}=0.19 ; \mathrm{P}=0.0034)$ (Fig. 1a), TyG-BMI-index $(r=0.43 ; \mathrm{P}=0.0001)$ (Fig. 1b), TyG-WC-index $(\mathrm{r}=0.44 ; \mathrm{P}=0.00001)$ (Fig. 1c), MI ( $\mathrm{r}=-0.17 ; \mathrm{P}=0.012)$ (Fig. 1d) and TG/HDL-C-ratio $(r=0.15 ; \mathrm{P}=0.011)$.

Several studies have demonstrated that TyG-index maintains good consistency with hyperinsulinemic-euglycemic clamp and HOMAIR [29]. Therefore, TyG-index provides more options for the evaluation of IR and prevention of IR-related diseases in clinical practice.

The association between SUA and FPG has not been fully outlined, in particular in HUA population. Although there has been more research on the connection between TyG-index and the risk of hypertension or T2DM, studies on the association of TyG-index with the HUA risk are still rare. There are currently only two cross-sectional studies exploring the relationship between TyG-index and HUA [30, 31]. In large-scale retrospective cohort study, we explored the longitudinal association of TyGindex with the HUA risk [32]. Furthermore, the author investigated whether the combination of TyG-index and some anthropometric indicators could improve that association: TyG-index was more associated with HUA risk than its components.

The IR/hyperinsulinemia can not only reduce the excretion of urate but also contribute to its overproduction. Generally, moderate levels of insulin suppress lipolysis efficiently in normal humans, but this effect will weaken in individuals with IR/hyperinsulinemia [33]. With the enhancement of lipolysis, excessive free fatty acids are generated, leading to dyslipidemia and the subsequent urate overgeneration [34].

TG/HDL-ratio and TyG-index are strongly associated with HUA regardless of BMI classification. These two obtainable and cost-effec- tive non-insulin-based IR indexes could be potential monitors during the HUA management and prevention of its IR-driven comorbidities. In a large-scale study, the article identified TG/HDL-ratio and TyG-index as indicators of IR in patients with HUA [31]. These simple and practical IR indicators are of substantial clinical importance for implementing preventive strategies against IR-driven comorbidities of HUA.

As Gu O., Hu X., Meng J. et al stated, TyG-index, a noninsulin-based IR index based on routine biochemical tests, was significantly associated with HUA risk in both sexes. The TyG combined with some obesity indicators may strengthen its association with the HUA risk in women but not in men. Thus, TyG-index and its related parameters have the potential to be used as risk grading tools for HUA prevention in clinical practice.

As the author has found, the most sensitive test to diagnose IR is a level TG $>1.46 \mathrm{mmol} / \mathrm{L}$ end TG/HDL-C-ratio > 1.37, at the same time, the most specific of the laboratory parameters is IRI $>15 \mu \mathrm{U} / \mathrm{ml}$ (78 \%) [35].

It should be noted that the ratio TG/HDLC-ratio is indicative of atherogenic dyslipidemia, but does not reflect IR development in patients with normolipidemia with existing disorders of glucose homeostasis. Unlike other calculated "non-insulin» indices IR, MI changes in glucose homeostasis and lipid metabolism. However, with negative dynamics of laboratory parameters it gradually increases [24]. MI provides IR qualitative and quantitative assessment and it can be recommended as an index for IR screening in clinical practice. Probability of $\mathrm{IR}$ absence for the value $\mathrm{MI} \leq 7.0$ makes up $93.6 \%$ (predictive value of a negative test result) [24].

Thus, «non-insulin» indices, calculated during the anthropometric and laboratory tests, widely used in clinical practice, significantly correlate with classical "insulin» indices and SUA concentration. They are more accessible and can be used to evaluate IR expressiveness in patients with T2DM and HUA. 


\section{CONCLUSIONS}

1. In patients with T2DM and HUA, there is a positive correlation of HOMA-IR from MI and AVI; QUICKI from MI, TyG-index, TyG-BMI-index, TyG-WC-index and AVI.

2. Among the calculated «non-insulin» indices IR from concentration SUA in patients with T2DM meaningfully associated TyG-index,
TyG-BMI-index, TyG-WC-index, MI and TG/ HDL-C-ratio.

3. For an adequate assessment of IR severity in patients with T2DM and HUA, it is advisable to use TyG-index, TyG-BMI-index, TyG-WC-index, MI and TG/HDL-C-ratio.

\section{REFERENCES}

1. Johnson RJ, Nakagawa T, Sanchez-Lozada LG, et al. Diabetes 2013; 62(10): 3307-3315. https://doi.org/10. 2337/db12-1814

2. Bailey CJ. Diabetes Obes Metab 2019; 21(6): 1291-1298. https://doi.org/10.1111/dom.13670

3. Kramer CK, von Mühlen D, Jassal SK, Barrett-Connor E. Diabetes Care 2009; 32(7): 1272-1273. https://doi. org/10.2337/dc09-0275

4. Juraschek SP, McAdams-Demarco M, Miller ER, et al. Am J Epidemiol 2014; 179 (6): 684-691. https://doi. org/10.1093/aje/kwt320.

5. Shani M, Vinker S, Dinour D, et al. J Clin Endocrinol Metab 2016; 101(10): 3772-3778. https://doi.org/10.1210/ jc.2016-2107.

6. Kodama S, Saito K, Yachi Y, et al. Diabetes Care 2009; 32(9): 1737-1742. https://doi.org/10.2337/dc09-0288.

7. Lv Q, Meng XF, He FF, et al. Plos One 2013; 8(2): e56864. https://doi.org/10.1371/journal.pone.0056864.

8. Bonora E, Targher G, Zenere MB, et al. Int J Obes Relat Metab Disord 1996; 20(11): 975-980.

9. Johnson RJ, Bakris GL, Borghi C, et al. Am J Kidney Dis 2018; 71(6): 851-865. https://doi.org/10.1053/j.ajkd. 2017.12.009

10. Li Z, Shen Y, Chen Y, et al. Biochem 2018; 45(3): 11561164. https://doi.org/10.1159/000487356.

11. Maharani N, Ting YK, Cheng J, et al. Circ J 2015; 79(12): 2659-2668. https://doi.org/10.1253/circj.CJ-150416 .

12. Yan M, Chen K, He L, et al. Biochem 2018; 45(5): 2122 2135. https://doi.org/10.1159/000488048.

13. Sheen A, Paquot N, Lefebore P. Diab Met Rev 1994; 10: 151-188. https://doi.org/10.1002/dmr.5610100206.

14. Rojtberg GE, Ushakova TI, Dorosh ZhV. Kardiologija 2004; 3: 94-101.

15. Bergman R, Finegood D, Ader M. Endocrine Rev 1985; 6: 45-86. https://doi.org/10.1210/edrv-6-1-45.

16. Mari A. Am J Physiol 1997; 272: 925-934.

17. Borona E, Moghetti P, Zancanaro C, et al. J Clin Endocrinol Metab 1989; 68: 374-378. https://doi.org/10.1210/ jcem-68-2-374.

18. Alberti KG, Zimmet PZ. Diabet Med 1998; 15: 539-553. https://doi.org/10.1002/(SICI)1096-9136(199807)15:7< 539::AID-DIA668>3.0. CO;2-S.
19. Matthews DR, Hosker JP, Rudenski AS, et al. Diabetologia 1985; 28(7): 412-419. https://doi.org/10.1007/ BF00280883.

20. Szapary PO, Bloedon LT, Samaha FF, et al. Arterioscler Thromb Vasc Biol 2006; 26(1): 182-188. https://doi.org/ 10.1161/01.ATV.0000195790. 24531.4f

21. Chen H, Sullivan G, Yue LQ, et al. Am J Physiol Endocrinol Metab 2003; 284(4): E804-812. https://doi. org/10.1152/ajpendo.00330.2002.

22. Melmer A, Lamina C, Tschoner A, et al. Obesity (Silver Spring) 2013; 21(4): 775-781. https://doi.org/10.1002/oby. 20289 .

23. Guerrero-Romero F, Simental-Mendía LE, GonzálezOrtiz M, et al. Clin Endocrinol Metab 2010; 95(7): 33473351. https://doi.org/10.1210/jc.2010-0288.

24. Rojtberg GE, Dorosh ZhV, Sharhun OO, et al. Racional'naja farmakoterapija v kardiologii 2014; 10(3): 264274. https://doi.org/10.20996/1819-6446-2014-10-3-264-274.

25. HOMA Calculator. The Oxford Centre for Diabetes, Endocrinilogy and Metabolism, available at: www.dtu. ox.ac.uk/homacalculator/index.php.

26. Katz A, Nambi SS, Mather K, et al. J Clin Endocrinol Metab 2000; 85(7):2402-2410. https://doi.org/10.1210/ jcem.85.7.6661.

27. Amato MC, Giordano C, Galia M. Diabetes Care 2010; 33(4): 920-922. https://doi.org/10.2337/dc09-1825.

28. Er LK, Wu S, Chou HH, et al. PLoS One 2016; 11: e0149731. https://doi.org/10.1371/journal.pone.0149731.

29. Sánchez-García A, Rodríguez-Gutiérrez R, MancillasAdame L, et al. Int J Endocrinol 2020; 10: 4678526. https://doi.org/10.1155/2020/4678526.

30. Shi W, Xing L, Jing L, et al. Postgrad Med 2019; 131(5): 348-356. https://doi.org/10.1080/00325481.2019.1624581.

31. Liu XZ, Xu X, Zhu JQ, et al. Clin Rheumatol 2019; 38(11): 3227-3233. https://doi.org/10.1007/s10067-019-04671-6.

32. Gu Q, Hu X, Meng J, et al. J Endocrinol 2020; 17: 3214716. https://doi.org/10.1155/2020/3214716.

33. Groop LC, Bonadonna RC, DelPrato S, et al. J Clin Invest 1989; 84(1): 205-213. https://doi.org/10.1172/JCI114142.

34. Bjornstad P, Eckel RH. Diab Rep 2018; 18(12): 127. https://doi.org/10.1007/s11892-018-1101-6.

35. McLaughlin T, Reaven G, Abbasi F, et al. Am J Cardiol 2005;96(3): 399-404. https://doi.org/10.1016/j.amjcard.2005.03.085. 


\title{
FEATURES OF INSULIN RESISTANCE ASSESSMENT IN PATIENTS WITH TYPE 2 DIABETES MELLITUS WITH HYPERURICEMIA
}

Cherniaieva A. A.

State Institution «V. Danylevsky Institute for Endocrine Pathology Problems

National Academy of Medical Sciences of Ukrainen, Kharkiv, Ukraine;

Kharkiv Medical Academy of Postgraduate Education, Ministry of Health of Ukraine, Kharkiv, Ukraine

annakholodnaja2008@gmail.com

Topicality. The link between hyperuricemia (HUA) and insulin resistance (IR) has been established in many studies, but the traditional «insulin» indices used to assess the severity of IR, although there are the most informative, sensitive and specific, have not been widely used in clinical practice.

The aim of the research is to evaluate the possibility to use calculated «non-insulin» indices in clinical practice to assess IR in patients with type 2 diabetes (T2DM) with HUA.

Materials and methods. We examined 395 patients with type 2 diabetes (231 women and 164 men) aged 39 to 81 years, the average - $(54.6 \pm 12.9)$ years, who received oral hypoglycemic therapy. Anthropometric indicators were determined - waist circumference (WC) and body mass index (BMI). The author determined the level of fasting blood glucose in capillary blood by glucose oxidase method, the concentration of uric acid (SUA) in the serum, the level of high-density lipoprotein cholesterol (HDL-C), triglycerides (TG) — by colorimetric method; immunoreactive insulin - by immunochemiluminescent method. The IR severity was assessed by indices HOMA-IR, QUICKI, Caro, visceral obesity index (AVI), triglyceride-glucose index (TyG-index), TyG-BMI index, TyG-WC index, metabolic index (MI) and the ratio of TG/cholesterol-HDL (TG/HDL-C-ratio). Statistical analysis of the obtained data was performed using the software package «Statgraphics Plus for Windows 10.0».

Results. Between groups of patients with T2DM on the concentration of SUA in the blood the author found significant differences in WC, BMI and TG level, which affected the calculated "non-insulin" indices: AVI $(\mathrm{P}=0.026)$, TyG-index $(\mathrm{P}=0.04)$, TyG-BMI-index $(\mathrm{P}=0.001)$, TyG-WC index $(\mathrm{P}=0.037)$ and $\mathrm{MI}(\mathrm{P}=0.03)$. A positive correlation between HOMA-IR and $\mathrm{MI}\left(\mathrm{r}_{\mathrm{s}}=0.44, \mathrm{P}=0.0006\right)$ and AVI $\left(\mathrm{r}_{\mathrm{s}}=0.28, \mathrm{P}=0.01\right)$ was established; QUICKI with MI ( $\left.\mathrm{r}_{\mathrm{s}}=0.32, \mathrm{P}=0.012\right)$, TyG-index $\left(\mathrm{r}_{\mathrm{s}}=0.29, \mathrm{P}=0.02\right)$, TyG-BMI index $\left(\mathrm{r}_{\mathrm{s}}=0.25, \mathrm{P}=0.04\right)$, TyG-WC index $\left(\mathrm{r}_{\mathrm{s}}=0.34, \mathrm{P}=0.004\right)$ and AVI $\left(\mathrm{r}_{\mathrm{s}}=0.31, \mathrm{P}=0.01\right)$. It has been determined that the Caro index at the trend level positively correlates with the TyG-index $\left(\mathrm{r}_{\mathrm{s}}=0.23, \mathrm{P}=0.065\right)$. Among the studied calculated «non-insulin» indices in patients with T2DM with the concentration of SUA in the blood are significantly associated with TyG-index $\left(r_{s}=0.19 ; \mathrm{P}=0.0034\right)$, TyG-BMI index $\left(r_{s}=0.43 ; P=0.0001\right)$, TyG-WC index $\left(r_{s}=0.44\right.$; $\mathrm{P}=0.00001)$, MI $\left(\mathrm{r}_{\mathrm{s}}=-0.17 ; \mathrm{P}=0.012\right)$ and TG/HDL-C-ratio $\left.\left(\mathrm{r}_{\mathrm{s}}=0.15\right) ; \mathrm{P}=0.011\right)$.

Conclusions. the author established a positive correlation between HOMA-IR and MI and AVI in patients with T2DM with SUA; QUICKI with MI, TyG-index, TyG-BMI-index, TyG-WC-index and AVI. Among the calculated «non-insulin» IR indices with the concentration of SUA in patients with T2DM are significantly associated with TyG-index, TyG-BMI-index, TyG-WC-index, MI and TyG/HS-HDL. To adequately assess the severity of IR in patients with T2DM with HUA, it is advisable to use TyG-index, TyG-BMI-index, TyG-WC-index, MI and TG/HS-HDL.

Keywords: insulin resistance, type 2 diabetes, hyperuricemia.

\section{ОСОБЛИВОСТІ ОЦІНКИ ІНСУЛІНОРЕЗИСТЕНТНОСТІ У ХВОРИХ НА ЦУКРОВИЙ ДІАБЕТ 2 ТИПУ 3 ГІПЕРУРИКЕМІЄЮ}

\author{
Черняева А. О. \\ ДУ «Інститут проблем ендокринної патологї ім. В.Я. Данилевського НАМН Украӥни», \\ м. Харків, Україна; \\ Харківська медична академія післядипломної освіти МОЗ України, \\ м. Харків, Україна \\ annakholodnaja2008@gmail.com
}

Актуальність. Зв'язок між гіперурикеміею (ГУ) і інсулінорезистентністю (IP) встановлено в багатьох дослідженнях, проте традиційні «інсулінові» індекси, що використовуються для оцінки виразності IP, хоча і є найбільш інформативними, чутливими і специфічними, не знайшли широкого застосування в клінічній практиці.

Мета дослідження - оцінити можливість використання в клінічній практиці для оцінки IP у хворих на цукровий діабет (ЦД) 2 типу з ГУ розрахункових «неінсулінових» індексів.

Матеріали і методи. Обстежено 395 хворих на ЦД 2 типу (231 жінка і 164 чоловіків) віком від 39 до 81 року, середній — $(54,6 \pm 12,9)$ років, які отримували пероральну цукрознижуючу терапію. Визначали антропометричні показники - обвід талії (OT) і індекс маси тіла (IMT). Рівень глікемії крові натще в капілярній крові визначали глюкозооксидазним методом, концентрацію сечової кислоти (СК) у сироватці крові, рівень холестерину ліпопротеїнів високої щільності (ХС ЛПВЩ), тригліцеридів (ТГ) - колориметричним методом; імунореактивного інсуліну — імунохемілюмінесцентним методом. Ступінь виразності IP оцінювали за індексами HOMA-IR, QUICKI, Caro, індексом вісцерального ожиріння (IBO), тригліцеридно-глюкозним індексом (ТуG-індекс), TyG-IMT-індексом, ТуG-OT-індексом, 
метаболічним індексом (MI) та відношенням ТГ/ХC ЛПВЩ. Статистичний аналіз отриманих даних проведено за програмним комплексом «Statgraphics Plus for Windows 10.0».

Результати. Між групами хворих на ЦД 2 типу за концентрацією СК в крові встановлено значущі відмінності за ОТ, IMT і рівнем ТГ, що позначилося на розрахункових «неінсулінових» індексах: IBO $(\mathrm{P}=0,026)$, ТуG-індекс $(\mathrm{P}=0,04)$, TyG-IMT-індекс $(\mathrm{P}=0,001)$, TyG-OT-індекс $(\mathrm{P}=0,037)$ та $\mathrm{MI}(\mathrm{P}=0,03)$. Встановлено наявність позитивного кореляційного зв'язку HOMA-IR з MI $\left(\mathrm{r}_{\mathrm{s}}=0,44, \mathrm{P}=0,0006\right)$ та IBO $\left(r_{s}=0,28, P=0,01\right)$; QUICKI з MI $\left(r_{s}=0,32, P=0,012\right)$, TyG-індекс $\left(r_{s}=0,29, P=0,02\right)$, ТуG-IMT-індекс $\left(r_{s}=0,25\right.$, $\mathrm{P}=0,04)$, TyG-OT-індекс $(\mathrm{r}=0,34, \mathrm{P}=0,004)$ і IBO $(\mathrm{r}=0,31, \mathrm{P}=0,01)$. Визначено, що індекс Саro на рівні тенденції позитивно корелюе з ТуG-індексом $\left(\mathrm{r}_{\mathrm{s}}=0,23, \mathrm{P}=0,065\right)$. Серед досліджуваних розрахункових «неінсулінових" індексів у хворих на ЦД 2 типу з концентрацією СК в крові значуще асоціюються ТуG-індекс $\left(\mathrm{r}_{\mathrm{s}}=0,19 ; \mathrm{P}=0,0034\right)$, ТуG-IMT-індекс $\left(\mathrm{r}_{\mathrm{s}}=0,43 ; \mathrm{P}=0,0001\right)$, ТуG-OT-індекс $\left(\mathrm{r}_{\mathrm{s}}=0,44 ; \mathrm{P}=0,00001\right)$, MI $\left(\mathrm{r}_{\mathrm{s}}=-0,17 ; \mathrm{P}=0,012\right)$ та ТГ/ХС-ЛПВШ $\left(\mathrm{r}_{\mathrm{s}}=0,15 ; \mathrm{P}=0,011\right)$

Висновки. У хворих на ЦД 2 типу з ГУ встановлено наявність позитивного кореляційного зв'язку HOMA-IR з MI та IBO; QUICKI з MI, TyG-індексом, TyG-BMI-індексом, TyG-WC-індексом і IBO. Визначено, що серед розрахункових «неінсулінових» індексів IP із концентрацією СК у хворих на ЦД 2 типу значуще асоціюються ТуG-індекс, TyG-IMT-індекс, ТуG-OT-індекс, MI та ТГ/ХC-ЛПВЩ. Для адекватної оцінки виразності IP у хворих на ЦД 2 типу з ГУ доцільно використовувати TyG-індекс, TyG-IMT-індекс, TyG-OT-індекс, МI та ТГ/ХС ЛПВШ.

К лючові слов : інсулінорезистентність, цукровий діабет 2 типу, гіперурикемія.

Cherniaieva Anna

https://orcid.org/0000-0002-2812-3323 